\title{
Tindakan Sosial Keterlibatan Perempuan dalam Jaringan dan Aksi Terorisme di Indonesia
}

\author{
Maria Ulfa $^{1 *}$, Robi Sugara ${ }^{1}$ \\ ${ }^{1}$ Universitas Islam Negeri Syarif Hidayatullah Jakarta, Indonesia \\ *Korespondensi: maria.ulfa@uinjkt.ac.id
}

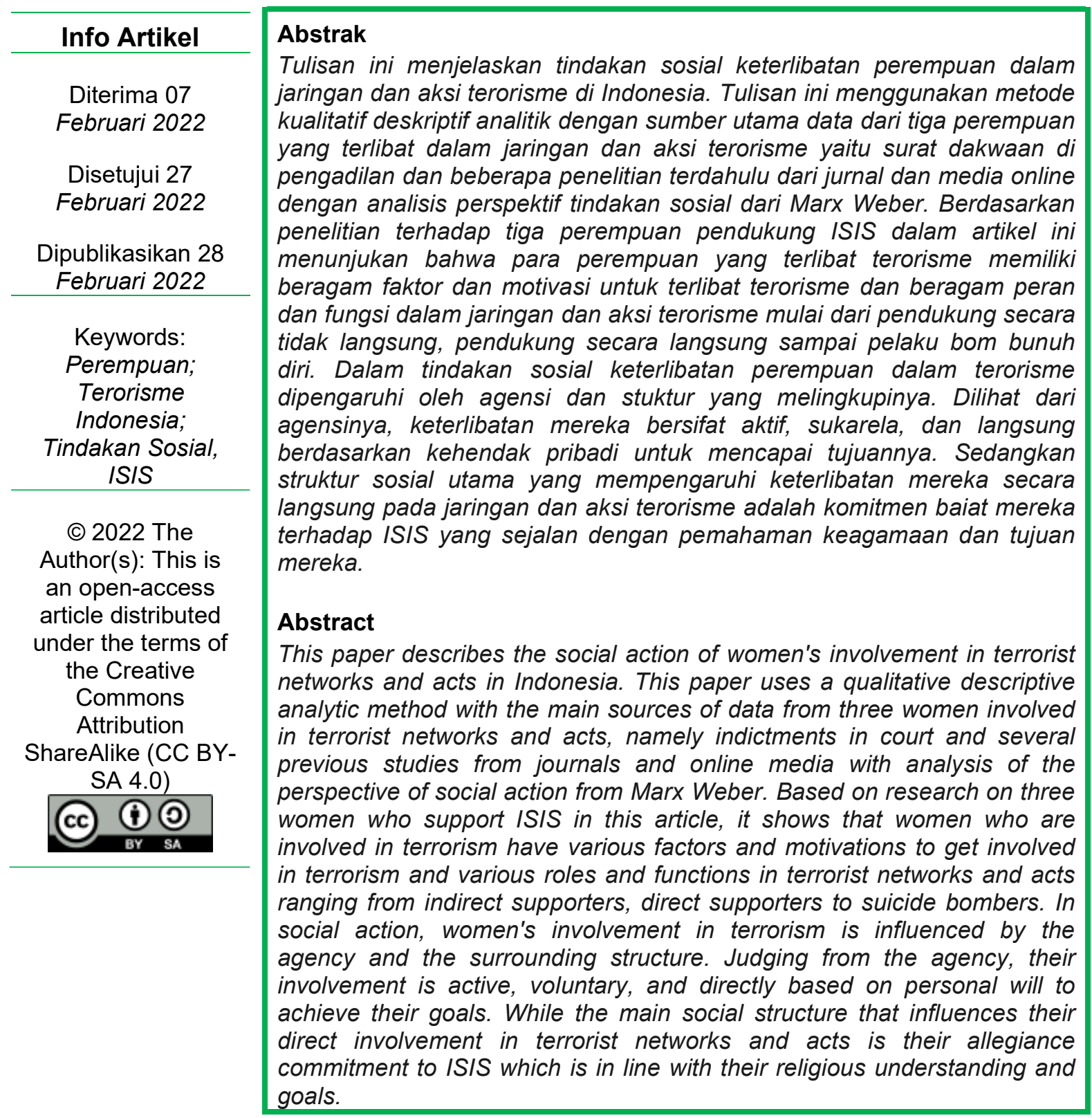




\section{Pendahuluan}

Sudah banyak media dan hasil penelitian yang telah mencatat aksi terorisme di Indonesia khususnya beberapa tahun belakangan ini yang tidak hanya dilakukan oleh laki-laki tetapi juga melibatkan perempuan. Beberapa penelitian sebelumnya membahas keterlibatan perempuan dalam aksi terorisme di Indonesia secara umum yang dilakukan secara individu dan juga bersama keluarga dimana kebanyakan mereka terlibat jaringan kelompok teroris Islamic State in Iraq and Syria (ISIS) (Amelia et al., 2020; Asiyah et al., 2020; Hartana, 2017; Kasanah, 2021; Mulia, 2018; Musfia, 2017; Nafisah, 2021; Qori'ah, 2019; Sukabdi, 2021; Wening \& Wahyudi, 2021; Widyaningsih \& Kuntarto, 2020; Wijaya, 2020; Rosyid, 2018). Hal ini karena pada aksi terorisme di Indonesia sebelum adanya ISIS, perempuan tidak dilibatkan secara langsung dalam aksi terorisme.

Keterlibatan perempuan dalam jaringan terorisme sebelum adanya ISIS hanya sebatas sebagai pendukung dengan beragam peran yang kebanyakan yang terlibat karena adanya hubungan pernikahan yaitu sebagai istri para terdakwa teroris. Beberapa perempuan yang terlibat kasus terorisme pada tahun 2004-2009 dan dijatuhi hukuman pindana diantaranya yaitu istri terdakwa teroris: Putri Munawaroh (istri Nurdin M. Top), Munfiatun (istri kedua Nurdin M. Top), Arina Rahma (istri ketiga Nurdin M. Top), Inggrid Wahyu Cahyaningsih (istri Sugeng Waluyo yang membantu pelaku teroris Bom Cimanggis), Rasidah binti Subari (istri Husaini bin Ismail pelaku pemboman di Singapura), Ruqayah binti Husen (istri Umar Patek), Deni Carmelita (istri Pepi Fernando pelaku bom buku dan bom Serpong), Rosmawati (kelompok Santoso), dan Nurul Azmy Tibyani (jaringan kelompok Santoso) (Bhakti, 2016). Keterlibatan mereka hanya sebagai memberikan bantuan dan ikut terlibat karena perbuatan suaminya dalam terorisme yang artinya pada periode ini para perempuan tidak terlibat langsung dalam jaringan dan aksi terorisme (Bhakti, 2016). Selain itu beberapa penelitian sebelumnya juga membahas istri terdakwa teroris yang diantaranya adalah Paridah sebagai istri dari Ali Ghufron alias Mukhlas pelaku Bom Bali I (Saputro, 2010), istri terdakwa teroris di Pekalongan Jawa Tengah (Maghfur \& Muniroh, 2013), dan beberapa istri narapidana terorisme di Jakarta, Semarang, dan Cilacap (Rufaedah et al., 2017).

Keterlibatan perempuan dalam jaringan dan aksi terorisme mengalami peningkatan peran dan jumlah sejak adanya deklarasi ISIS pada 2014. Perempuan terlibat dalam jaringan dan aksi terorisme tidak hanya sebagai pendukung (supporter) tetapi sebagai pelaku (aktor). Beberapa pelaku terorisme perempuan beberapa tahun belakangan ini yaitu Dian Yulia Novi (terdakwa kasus percobaan bom bunuh diri dengan bom panci di Istana Negara pada 10 Desember 2016), Tutin Sugiarti (terdakwa kasus bom panci pada 10 Desember 2016), dan Ika Puspitasari (terdakwa pelaku percobaan bom bunuh diri di Bali pada akhir 2016) (Utama, 2017). Selain itu beberapa tindakan terorisme dilakukan oleh perempuan lainnya yaitu: Puji Kuswati yang melakukan bom bunuh diri bersama keluarganya dengan suami dan empat anaknya di tiga gereja di Surabaya pada 13 Mei 2018, Tri Ernawati yang melakukan bom bunuh diri bersama suami dan tiga anaknya di Polrestabes Surabaya pada 14 Mei 2018, Solimah (istri Abu Hamzah terdakwa teroris asal Sibolga) yang melakukan bom bunuh diri dengan anaknya pada 12 Maret 2019 di Sibolga, dan Ulfah Handayani Saleh (deportan dari Turki) yang melakukan bom bunuh diri dengan suaminya di gereja Katedral Jolo, Filipina pada 
2019 (Detik.com, 2021). Beberapa perempuan lainnya yaitu Yogi Shafitri Fortuna yang melakukan bom bunuh diri dengan suaminya di gereja Katedral Makassar pada 28 Maret 2021 dan Zakiyah Aini yang menyerang petugas di pos keamanaan Mabes Polri Jakarta dengan senjata softgun pada 31 Maret 2021 (Al Habsy, n.d.; Azanella, 2021; CNN Indonesia, 2021; Qori'ah, 2019; Rizky, 2021).

Berdasarkan latar belakang ini, dapat dilihat bagaimana perempuan terlibat secara langsung dalam jaringan dan aksi terorisme di Indonesia. Untuk itu artikel ini fokus membahas tindakan sosial dari tiga perempuan sebagai pelaku tindakan terorisme di Indonesia yang merupakan jaringan kelompok teroris ISIS. Mereka adalah Anggi Indah Mulia, Dian YulisaNovi, dan Tutin Sugiarti. Ketiga perempuan ini memiliki kesamaan latar belakang yaitu sebagai pendukung ISIS dengan latar belakang Anggi sebagai pekerja migran di Hongkong, Dian sebagai pekerja migran di Taiwan, sedangkan Tutin terlibat dalam kasus Dian yang membantu rencana aksi bom bunuh diri. Selain itu ketiganya terlibat jaringan ISIS utamanya melalui media sosial dan aktivitas mereka dalam aksi terorisme yang membuat mereka ditangkap dilakukan dalam periode waktu yang berdekatan yaitu tahun 2015-2017. Penelitian terhadap tindakan sosial keterlibatan mereka sebagai perempuan dalam jaringan dan aksi terorisme untuk melihat lebih mendalam tindakan perempuan dalam terorisme secara lebih khusus dari pemikiran, sikap, perjalanan, dan pengalaman mereka. Sebagaimana dalam perspektif Marx Weber di mana seseorang melakukan suatu tindakan berdasarkan atas persepsi, pengalaman, dan pemahaman pada suatu obyek stimulus atau situasi tertentu. Tindakan sosial Weber ini berkaitan dengan interaksi sosial dan tujuan dari tindakan sosial tersebut.

\section{Metode Penelitian}

Penelitian kualitatif ini menggunakan dokumen surat dakwaan sebagai sumber utama yaitu surat dakwaan dari ketiga perempuan terlibat kasus terorisme yang bernama Anggi Indah Mulia, Dian Yulis Novi, dan Tutin Sugiarti dan sumbersumber terkait seperti jurnal dan media online. Surat dakwaan adalah sebuah dokumen yang berisikan biodata seorang terdakwa beserta informasi terkait keterlibatan dalam kasus yang didakwanya. Surat ini digunakan oleh Jaksa Penuntut Umum (JPU) di pengadilan dalam proses pengadilan seseorang.

Penelitian ini mengkaji tindakan sosial tiga perempuan yang terlibat kasus terorisme tersebut dalam melakukan aksi terorismenya. Penelitian ini menggunakan teori tindakan sosial dari Max Weber untuk menganalisis data secara deskriptif analitik. Tindakan sosial ini adalah tindakan yang berorientasi pada tujuan dan motivasi dari pelakunya. Weber mengklasifkasi tindakan sosial menjadi empat tipe. Pertama yaitu tindakan tradisional yang berarti "saya melakukan ini karena saya selalu melakukannya." Kedua adalah tindakan afektif yang berarti "Apa boleh buat saya lakukan." Ketiga yakni tindakan berorientasi nilai atau penggunaan rasionalitas nilai yang berarti "yang saya tahu hanya melakukan ini." Dan keempat tindakan yang berorientasi tujuan atau penggunaan rasionalitas instrumental yang berarti "Tindakan ini paling efisien untuk mencapai tujuan ini dan inilah cara terbaik untuk mencapainya" (Jones et al., 2010, 114-115)

Teori tindakan sosial (social action) Weber ini fokus pada kehidupan sosial di tingkat mikro yaitu hubungan sosial dari cara individu berinteraksi dengan yang lain secara individual dan bukan di tingkat makro yaitu cara seluruh struktur 
masyarakat mempengaruhi perilaku individu. Dalam teori tindakan, masyarakat bukanlah penyebab tetapi merupakan hasil akhir dari interaksi antar manusia dimana keteraturan sosial dapat dilihat dari bagaimana manusia berinteraksi. Tindakan manusia adalah sukarela dan produk dari pikiran yang menghasilkan keputusan untuk bertindak dan memilih tindakan dengan cara tertentu dengan tujuan tertentu. Teori tindakan sosial ini menekankan pada keputusan yang dipilih seseorang sesuai dengan interpretasi pada dunia di sekelilingnya (Jones et al., 2010, 24-25).

Tindakan aktor dipengaruhi oleh agensi dan struktur. Dalam konsep Weber, agensi adalah "kemampuan seseorang (aktor/agen) untuk berpikir, bersikap dan bertindak secara independen, bebas, dan otonom, sesuai dengan kehendaknya sendiri". Agensi seseorang dipengaruhi oleh beragam faktor yang mencakup faktor internal dan ekstrenal (Kinseng 2017). Kemudian struktur yang mempengaruhi tindakan aktor yaitu struktur sosial dan struktur fisikal material atau non-sosial. Struktur ini meliputi enam bentuk yaitu wacana atau diskursus, aturan-aturan termasuk norma dan adat istiadat, para aktor sosial lain selain aktor diri sendiri, tindakan para aktor sosial, stratifikasi sosial dan kelompok-kelompok sosial, dan sumber daya fisik baik alam atau non-alam (Kinseng, 2017, 129).

\section{Hasil dan Pembahasan}

Pembahasan penelitian ini dibagi menjadi dua bagian. Bagian pertama yaitu mengenai keterlibatan perempuan dalam jaringan dan aksi terorisme yang dibagi menjadi tiga sub-bagian yaitu tindakan sosial keterlibatan Anggi Indah Mulia, Dian Yulis Novi, dan Tutin Sugiarti. Bagian kedua yaitu mengenai tindakan sosial dalam jaringan ISIS dan aksi terorisme. Bagian terakhir sebagai penutup adalah kesimpulan.

\subsection{Keterlibatan Perempuan dalam Jaringan dan Aksi Terorisme}

Kajian tentang keterlibatan perempuan dalam jaringan dan aksi terorisme setidaknya terbagi dalam dua pertanyaan besar yaitu pertama keterlibatan perempuan sebagai pelaku dan kedua keterlibatan perempuan sebagai korban. Keterlibatan perempuan dalam jaringan dan aksi terorisme khususnya setelah adanya deklarasi ISIS pada 2014. Dalam kasus ISIS, perempuan terlibat terorisme secara langsung karena keberhasilan pengunaan manipulasi informasi dan propaganda ISIS di media sosial dan kanal aplikasi komunikasi dengan pemanfaatan teknologi internet. Para perempuan tertarik untuk terlibat dalam kelompok-kelompok teroris khususnya ISIS karena beragam faktor penarik dan pendorong. Propaganda tersebut berhasil membentuk persepsi perempuan untuk bergabung pada kelompok-kelompok ISIS (Wijaya, 2020).

Pergerakan jaringan terorisme internasional dan pemanfaatan teknologi informasi internet oleh kelompok terorisme merupakan salah satu katalisator keterlibatan perempuan dalam terorisme. Hal ini menjadi suatu pola, modus, dan strategi baru secara global sehingga terjadi pergeseran peran sosial perempuan di lingkaran jaringan terorisme yang sebelumnya terkait dengan sifat feminitas dengan ranah privat di rumah tangga menjadi aktivitas terorisme dengan sifat maskulinitas yang biasanya dilakukan laki-laki (Hartana, 2017).

Secara umum, perempuan terlibat radikalisme dan terorisme disebabkan oleh beberapa faktor yaitu faktor agama, ideologis (memperjuangkan keadilan), tekanan 
kelompok, politik (kemiskinan, ketimpangan sosial dan diskriminasi), dan alasan pribadi (Mulia, 2018; Widyaningsih \& Kuntarto, 2020). Sedangkan keterlibatan perempuan dalam kelompok teroris ISIS di Indonesia karena beberapa alasan diantaranya karena faktor kepribadian (seperti narsistik, fanatik, religius, dan psikopatologi), latar belakang personal, orang terdekatnya yang terlibat terorisme lebih dahulu, dan identitas sosial melalui solidaritas Muslim untuk pembalasan dendam terhadap apa yang menimpa Muslim di luar negeri seperti Suriah dan Palestina (Musfia, 2017). Motivasi pendorong dan penarik lainnya seperti adanya perasaan merasa bertanggung jawab sebagai ibu untuk mendidik anak-anaknya, motivasi memperjuangkan Islam yang dilecehkan oleh non-Muslim dengan perjuangan dari perempuan yang dianggap kaum lemah sehingga keterlibatan dalam ISIS dianggap sebagai simbol perlawanan perempuan, dan motivasi pencarian indentitas, kepemilikan dan petualangan cinta melalui ISIS (Wijaya, 2020). Fenomena ini berbeda dengan kasus terorisme lama di Indonesia seperti kelompok Jamaah Islamiyah (JI) dan Jamaah Ansharu Tauhid (JAT) yang tidak banyak melibatkan perempuan (Musfia, 2017).

Selain itu, perempuan terlibat dalam jaringan dan aksi terorisme di Indonesia juga karena beberapa faktor lainnya. Pertama yaitu adanya tindak penangkapan teroris yang dilakukan aparat yang disaksikan oleh kerabat atau keluarga khususnya anak-anak para teroris sehingga menimbulkan trauma dan dendam kepada aparat. Kedua yaitu kondisi ekonomi keluarga teroris yang kekurangan dan tidak ada yang memperhatikan sehingga membuat istri pelaku bom yang dipenjara atau dihukum mati mengikuti jejak suaminya untuk melakukan bom bunuh diri agar dapat segera bertemu suaminya di surga. Hal ini juga dapat dipengaruhi oleh jaringan teroris yang memanfaatkan keterdesakan ekonomi tersebut. Ketiga yaitu anak-anak mengidolakan ayahnya yang merupakan pelaku teror dan ini dipengaruhi oleh peran ibu sebagai pendidik anak-anaknya di rumah (Saputro, 2010).

Sedangkan penyebab perempuan terlibat terorisme sebagai kombatan untuk melakukan bom bunuh diri setidaknya ada enam faktor yaitu penyimpangan indoktrinasi jihad, iming-iming masuk surga, bersuamikan teroris, perasaan terdiskriminasi, dan rasa frustasi sehingga mengganggap bom bunuh diri sebagai jalan pertobatan dan upaya balas dendam karena menjadi korban pelecehan seksual (Kasanah, 2021). Dari berbagai kasus perempuan terlibat terorisme ISIS dapat dilihat polanya yang terbagi menjadi tiga yaitu gerakan sel ISIS dengan seluruh anggotanya perempuan seperti kelompok Brigade al Khansa jaringan ISIS yang dibentuk 2014 oleh warna Inggris, gerakan sel keluarga yang mendukung suami yang sebagai pendukung ISIS, dan gerakan terror yang dilakukan perseorangan (Wijaya, 2020).

Perempuan dalam jaringan terorisme ISIS di Indonesia memiliki beberapa peran dan posisi yang beragam. Dalam kasus kelompok teroris Mujahidin Indonesia Timur (MIT) pimpinan Santoso, peran perempuan diantaranya yaitu sebagai follower atau simpatisan atau sponsor finansial, perekrut, middle management, hingga pelaku teror bom bunuh diri (Musfia, 2017). Secara umum, peran perempuan dalam jaringan terorisme dibagi menjadi empat yaitu: 1) pendukung tidak langsung yang tidak terlibat aksi terorisme secara langsung tetapi memberikan dukungan materi, finansial, dan sikap sosial yang disebut follower atau simpatisan, 2) pendukung secara langsung aksi terorisme dengan membantu 
penyediaan logistik, perantara penerima uang, dan perekrut, 3) pelaku bom bunuh diri atau martir dan 4) pemimpin kelompok jaringan teroris (Hogg, Abrams, Otten, dan Hinkle 2004 dalam Musfia, 2017; lihat juga Bigio \& Vogelstein, 2019; Ikhsan, 2020; (Wijaya, 2020).

Dengan kata lain, tugas dan peran perempuan dalam gerakan terorisme yang cukup beragam dan signifikan itu diantaranya sebagai pendidik, agen perubahan, pendakwah, pengumpul dana, perekrut, penyedia logistik, pengantin atau pelaku bom bunuh diri, kurir antar kota antar negara, penghubung rahasia (mata-mata), agen radikal, pengikut dan pendamping setia dari suami teroris (Mulia, 2019). Selain itu perannya juga sebagai informan, pelindung manusia (human shield) atau sekedar pemuas kebutuhan seks teroris laki-laki, pengelola penerbitan organisasi fundamentalisme di internet (Mulia, 2018).

Berdasarkan beberapa kajian sebelumnya dan khususnya penelitian risk assessment keterlibatan perempuan terlibat terorisme di Indonesia dimana para perempuan terlibat terorisme itu memiliki beragam peran dan fungsi seperti yang disebutkan sebelumnya, sehingga dapat disimpulkan bahwa perempuan yang terlibat gerakan dan kelompok-kelompok terorisme dapat disebut sebagai pelaku (aktor) daripada sebagai korban dari masyarakat patriarkal (Sukabdi, 2021). Perempuan sebagai aktor atau pelaku aktif merupakan salah satu pengembangan taktik teror dalam aksi terorisme di Indonesia. Dalam hal ini perempuan digunakan sebagai kamuflase kelompok teroris dalam melakukan aksi terorisme. Namun demikian para perempuan juga memiliki motivasi yang berperan penting sebagai penggerak aksi terorisme perempuan diantaranya yaitu faktor ekonomi, keadilan, aktualisasi diri dan sosial (Amelia et al., 2020).

Karena itu, selain disebut sebagai aktor terorisme, perempuan yang terlibat terorisme juga dipandang sebagai korban terorisme. Hal ini karena keterlibatan perempuan dalam terorisme tidak terlepas dari dominasi patriakhi. Hegemoni patriarkhi berkontribusi besar terhadap perempuan dalam indoktrinasi pemaknaan jihad dan implementasinya yang dilakukan dalam keluarga melalui pernikahan maupun hubungan sebelum pernikahan (Asiyah et al., 2020). Karena itu meskipun perempuan berperan sebagai aktor utama dan subyek pelaku bom dalam gerakan terorisme, tetapi sebenarnya mereha adalah korban yaitu korban dari ideologi keluarga atau suami, korban indoktrinasi agama yang dianggapnya tidak memihak kemanusiaan, korban media, korban stigmatisasi dari masyarakat, dan juga korban dari ekses konflik. Dengan kata lain perempuan dalam gerakan fudamentalisme dan terorisme merupakan korban dari keadaan yang diciptakan oleh para elit kekuasaan patriarki (Mulia, 2019).

Selain itu dalam aksi terorisme yang sebelumnya berwajah maskulin dengan pendekatan patriarkal, keterlibatan perempuan dalam terorisme ini karena dimanfaatkan untuk terlibat langsung sebagai pelaku dengan pendekatan feminin. Perempuan dimanfaatkan kelompok teoris, mulai dari perannya dalam menyembunyikan pelaku teror yang biasanya karena adanya hubungan pernikahan sampai kegiatan intelijen untuk mengumpulkan informasi target teror dimana perempuan dianggap lebih efektif tanpa menimbulkan kecurigaan. Karena itu dalam konteks ini faktanya beberapa perempuan adalah pelaku terorisme yang menjadi aktor kunci aksi terorisme namun hakikinya mereka adalah korban. Dalam hal ini korban dari ketidaktahuan dan ketidakberdayaan yang dimanfaatkan oleh kelompok teroris (Asiyah et al., 2020). Namun demikian, apapun peran perempuan 
dalam lingkar terorisme yang beragam tersebut, identitas dominan yang muncul bagi mereka adalah menganggap dirinya sebagai jihadis sehingga identitas ini mempengaruhi perilaku sosial mereka dan pandangan mereka (Kurnia \& Sukabdi, 2021). Karena itu pada bagian pembahasan berikut dibahas tindakan sosial tiga perempuan yang terlibat langsung dalam aksi terorisme di Indonesia.

\section{a. Tindakan Sosial Keterlibatan Anggi Indah Kusuma}

Berdasarkan dokumen surat dakwaan Anggi Indah Kusuma (Kejaksaan Negeri Jakarta Barat, 2018) yang berisikan biodata terdakwa dan informasi terkait keterlibatan dalam kasus yang didakwanya yakni terorisme dapat dikaji bagaimana tindakan sosial keterlibatan Anggi Indah Kusuma (lahir 11 Juni 1993 di Klaten) dalam jaringan dan aksi terorisme di Indonesia. Anggi Indah Kusuma alias Khanza Syafiyah Al Furqon ditangkap pada 2017 atas tuduhan perencanaan aksi terorisme di Bandung.

Anggi ditangkap bersama suaminya yang bernama Rahman dimana mereka adalah pendukung ISIS atau dikenal juga dengan sebutan Ansharu Daullah. Keterlibatan Anggi dalam jaringan terorisme awalnya dipengaruhi media sosial khususnya Facebook yang berisi konten propaganda tentang ISIS yang sangat masif pada tahun 2016 ketika dia masih bekerja sebagai pekerja migran di Kota Yuen, Hongkong. Kemudian melalui Facebook, Anggi berkenalan dan kemudian berkomunikasi dengan beberapa pendukung ISIS secara intens. Dari pertemanan melalui media sosial tersebut, Anggi mendapatkan informasi dan penjelasan mengenai Khilafah Islamiyah dan profil Abu Bakar Al-Bagdadi yang mendeklarasikan negara Islam yang disebut oleh mereka sebagai khalifah. Anggi kemudian tertarik dan berbaiat kepada ISIS yang divideokan dari Hongkong dan diunggah di akun pribadi Facebook-nya pada Maret 2017. Tujuan diunggahnya video tersebut untuk memberi semangat para mujahidin untuk melakukan jihad di wilayah ISIS. Setelah bergabung dengan ISIS, Anggi membuat dua group Telegram dan beberapa beberapa channel berita yang isinya propaganda untuk mendukung ISIS (Kejaksaan Negeri Jakarta Barat, 2018).

Setelah unggahan video baiat Anggi pada ISIS di Facebook tersebut, dia dideportasi oleh pemerintah Hongkong. Dia kemudian direhabilitasi oleh pemerintah Indonesia dan dipulangkan ke rumah orang tuanya di Klaten, Jawa Tengah. Anggi kemudian menghubungi kenalannya di Facebook yang bernama Adilatul Rahmah (asal Sumenep) yang bekerja sebagai buruh migran di Malaysia untuk membahas pernikahan mereka, meskipun tidak disetujui oleh orangtua Anggi. Mereka kemudian menikah pada 2017 tanpa dihadiri wali orangtua dan tinggal di Bandung (Kejaksaan Negeri Jakarta Barat, 2018).

Selama tinggal di Bandung, Anggi bertemu dengan para pendukung ISIS lainnya. Mereka pernah diajak hijrah oleh kelompok jaringan ISIS di Bandung ke Marawi, Filipina untuk membantu kelompok pendukung ISIS, tetapi Anggi tidak dapat berangkat karena tidak memiliki KTP dan passport pasca dideportasi dari Hongkong. Karena itu mereka berencana melakukan aksi teror di Bandung dengan target PT PINDAD dengan tujuan untuk mengambil senjata api atau Mako Brimob Kelapa Dua, Depok sebagai target simbol perlawanan pada pemerintah Indonesia (Kejaksaan Negeri Jakarta Barat, 2018).

Sebelum melakukan aksi bom, mereka diminta melakukan aksi fai (perampokan) sebagai modal pembuatan bom. Akan tetapi mereka tidak mau 
melakukan itu sehingga biaya pembuatan bom atas biaya masing-masing. Mereka membeli bahan-bahan peledak dan merakitnya sendiri. Pada saat itu kondisi Anggi sedang hamil. Rencana aksi terorisme mereka gagal karena Anggi kemudian ditangkap pada 2017 (Kejaksaan Negeri Jakarta Barat, 2018).

Berdasarkan perjalanan Anggi sebagai salah satu aktor dalam jaringan kelompok terorisme ini, dapat dilihat proses perkenalan Anggi pada kelompok teroris ISIS sampai bergabung dan berbaiat merupakan salah satu keberhasilan dari propaganda kampanye ISIS di internet melalui media sosial. Melalui media sosial inilah terjalin hubungan perkenalan dan indoktrinasi atau radikalisasi oleh jaringan kelompok ISIS hingga akhirnya Anggi menjadi bagian dari aktor dalam jaringan dan aksi terorisme.

Dilihat dari tindakan sosialnya, dalam konsep agensi, Anggi menentukan sikap dan tindakannya sesuai dengan kehendaknya mulai dari menentukan sikap bergabung dengan ISIS, melakukan propaganda ISIS melalui grup-grup Telegram yang dibuatnya, setuju untuk hijrah ke Filipina untuk mendukung ISIS (Arnaz, 2018) namun batal karena tidak memiliki kelengkapan identitas seperti KTP dan passport, dan berencana melakukan aksi teror di Bandung dengan menggunakan bom. Akan tetapi, Anggi tidak bersedia melakukan fai terlebih dahulu untuk biaya pembuatan bom dan aksi terornya hingga akhirnya dia bersedia mengeluarkan uang untuk pembuatan bom. Penolakan Anggi untuk melakukan fai terlebih dahulu, bisa disebabkan karena dia dan suaminya tidak memiliki pengalaman untuk melakukan fai sebagaimana umum dilakukan kelompok teror sejak aksi Bom Bali 2002 dimana fai menjadi sesuatu keharusan untuk membiayai aksi teror (Maharani, 2013).

Berdasarkan teori tindakan sosial bahwa keterlibatan Anggi dalam jaringan dan aksi terorisme tidak terlepas dari agensi dan struktur sosial yang ada. Tindakan sosial Anggi dalam keterlibatannya pada jaringan dan aksi terorisme dalam beberapa kegiatan terkait terorisme merupakan tindakan yang dilakukannya secara aktif, sukarela dan langsung yang berdasarkan pemikiran dan keputusannya dalam bertindak dan memilih tindakan dengan cara tersebut khususnya dalam propaganda ISIS di media sosial dan terlibat dalam pembuatan bom serta rencana teror bom dengan tujuan yang menurut interpretasinya adalah jihad. Keterlibatan dan tindakan Anggi dalam jaringan ISIS ini juga tidak mendapatkan hambatan sosial secara gender dimana jaringan dan aksi terorisme didominasi oleh laki-laki. Bahkan ketika pembuatan dan perencanaan aksi teror bom kondisi Anggi sedang dalam keadaan hamil.

Secara struktur, tindakan Anggi dipengaruhi beberapa faktor internal dan eksternal. Anggi bukanlah lulusan perguruan tinggi. Dia adalah perempuan asal Jawa yang bekerja sebagai pekerja migran di Hongkong yang kemudian aktif menjadi pendukung ISIS. Karena tindakannya menggunggah video baiatnya kepada ISIS di akun Facebook-nya, membuat dia dideportasi dari Hongkong sekaligus kehilangan pekerjaannya. Dukungannya terhadap ISIS dan telah menjadi bagian dari kelompok ISIS inilah yang utamanya membuat struktur sosial Anggi berani dalam tindakannya terlibat dalam jaringan teroris dan aksi terorisme. Merujuk pada klasifikasi tindakan sosialnya Weber, tindakan Anggi ini dapat dikatakan termasuk dalam tiga tipe tindakan sosial yaitu sebagai tindakan afektif yang dapat dilakukannya berdasarkan keinginannya untuk bergabung ISIS, melakukan propaganda ISIS melalui media sosia, dan melakukan tindakan teror 
bom, tindakan berorientasi nilai dengan melakukan teror bom sebagai jihad, dan tindakan yang berorientasi tujuan atau penggunaan rasional instrumental untuk mencapai tujuan yaitu dengan menanggap teror bom sebagai tindakan yang efisien untuk mencapai tujuan yaitu berjihad.

\section{b. Tindakan Sosial Keterlibatan Dian Yulia Novi}

Pembahasan mengenai tindakan sosial keterlibatan Dian Yulia Novi dalam jaringan dan aksi terorisme ini utamanya berdasarkan data dari dokumen surat dakwaan Dian Yulia Novi alias Dian alias Ukhti alias Ayatul Nissa binti Asnawi (Kejaksaan Negeri Jakarta Timur, 2017a) Dokumen ini berisikan biodata terdakwa dan informasi terkait keterlibatan dalam kasus yang didakwanya yakni terorisme. Dian Yulia Novi ditangkap pada 16 Desember 2016 oleh Densus 88 atas perencanaan aksi bom bunuh diri untuk target rombongan Pasukan Pengawalan Presiden (Paspampres) dan Mako Brimob Kelapa Dua Depok, Jawa Barat.

Dian lahir di Cirebon, 4 Juli 1989. Pendidikan terakhirnya yaitu SMA BPPI Balai Indah Bandung, Jawa Barat. Dian mulai tertarik ISIS melalui media sosial ketika masih bekerja sebagai buruh migran di Taiwan pada tahun 2015. Dian mengenal ISIS melalui media sosial khususnya Facebook dan beberapa situs jaringan ISIS. Melalui media-media terkait ISIS tersebut dia tidak hanya mengenal jihad, daulah islamiyah, suriah dan ISIS, tetapi juga bergabung dengan para pendukung ISIS baik laki-laki maupun perempuan. Dia kemudian termotivasi untuk melakukan istisyadiyah yaitu melakukan aksi bom bunuh diri. Dia berkomunikasi dengan Tutin Sugiarti melalui media sosial pada tahun 2015 dan menyampaikan kepada Tutin bahwa dia ingin melakukan bom bunuh diri tetapi dia ingin menikah terlebih dahulu (Kejaksaan Negeri Jakarta Timur, 2017a).

Pada tahun 2016 Dian kembali ke Indonesia dari Taiwan dan pada September 2016 Tutin menemui Dian untuk memastikan rencana Dian untuk melakukan aksi bom bunuh diri. Dian ingin melakukan itu untuk memberikan syafaat surga kepada orang tuanya yang menurutnya sudah batal keislamannya karena mempercayai dukun untuk pengobatan sakitnya. Kemudian Tutin menghubungi Muhammad Nur Solikin alias Abu Ghurob alias Abu Abdullah bin Nurhadi yang merupakan jaringan kelompok ISIS untuk dikenalkan dan dinikahkan kepada Dian. Muhammad lalu menghubungi Dian melalui Telegram dan mengajak Dian untuk menikah. Pada Oktober 2016, Dian menikah secara jarak jauh dengan Muhammad diwakilkan oleh wali orang lain (Kejaksaan Negeri Jakarta Timur, 2017a).

Setelah menikah, Muhammad menemui Dian di Cirebon dan memberikan penjelasan tentang jihad, tauhid, mati syahid dan Daulah Islamiyah. Muhammad menemui Dian lagi untuk membimbing Dian dalam melakukan baiat lagi kepada ISIS. Pada Desember 2016 Muhammad mengantar Dian ke rumah kontrakan di Bekasi. Muhammad kemudian membuat bom rakitan di daerah asalnya di Solo bersama dengan beberapa rekannya dengan petunjuk pembuatan bom dari Bahrum Naim. Bom Panci itu kemudian dibawa ke rumah kontrakan Dian di Bekasi. Setelah itu, Dian meneriman pesan Telegram dari Bahrum Naim tentang target amaliyah yaitu pada saat latihan Paspamres melakukan latihan pada 11 Desember 2016 pagi hari dan jika gagal target kedua adalah pengawal dari Basuki Tjahaja Purnama atau dikenal dengan panggilan Ahok (Gubernur Jakarta tahun 2014-2017 yang non-Muslim) atau target lainnya adalah di depan masjid Mako 
Brimob Kepala Dua Depok. Muhammad dan temannya membantu survei lokasi target hingga akhirnya pada 10 Desember 2016 pagi, Muhammad bersama temannya menemui Dian dan memberikan bom panci. Setelah bertemu, Dian mengirim surat wasiat untuk orangtuanya di Cirebon melalui kantor pos. Dian kemudian membawa tas berisikan bom ke kontrakannya. Sebelum bom diledakan, pada sore hari itu Dian ditangkap oleh kepolisian di kontrakannya (Kejaksaan Negeri Jakarta Timur, 2017a).

Berdasarkan perjalanan Dian dalam mengenal dan bergabung pada kelompok ISIS, Dian mengenal ISIS melalui media sosial dan beberapa situs propaganda ISIS. Dian juga merupakan salah satu hasil dari keberhasilan propaganda yang dilakukan ISIS di media sosial. Dian dengan inisiatifnya sendiri menghubungi jaringan kelompok ISIS untuk menyampaikan kesediannya untuk melakukan bom bunuh diri.

Dalam teori tindakan sosial, keterlibatan Dian dalam jaringan dan aksi terorisme tidak terlepas dari agensi dan struktur sosial yang melingkupinya. Tindakan sosial Dian adalah keterlibatan secara aktif, sukarela dan langsung dengan bersedia menjadi pelaku bom bunuh diri atas dasar pemikiran dan keputusannya pribadi. Dalam konsep agensi, tindakan Dian ini dipengaruhi oleh faktor internal dan eksternal. Setelah bergabung dengan ISIS, Dian percaya bahwa aksi bom bunuh diri adalah bagian dari jihad. Selain itu, kerelaan dalam aksi untuk bom bunuh diri juga didorong oleh tindakan orang tuanya yang dianggapnya telah batal secara keislamannya karena percaya dukun untuk pengobatan, sehingga dia ingin menolong orang tuanya dengan percaya dapat memberikan syafaat surga kepada orangtuanya melalui tindakan bom bunuh diri. Dalam surat wasiat yang ditulis oleh Dian, dia mengatakan bahwa aksi bom bunuh dirinya adalah bagian dari pengabdian dirinya kepada Tuhan dan berbakti kepada orang tua yang diiyakininya dapat membawanya ke surga bersama keluarganya (Abdul, 2016). Namun demikian, Dian tidak memiliki kemampuan secara agensi untuk melakukan aksi bom bunuh diri secara sendiri. Karena itu dia menghubungi Tutin sebagai jaringan ISIS untuk membantunya menghubungkan dengan seseorang dari jaringan ISIS yang dapat memfasilitasi rencananya sekaligus menjadi suaminya yaitu Muhammad Nur Solikin.

Dengan demikian dapat dikatakan tindakan Dian lebih banyak dipengaruhi struktur sosialnya utamanya dari faktor internal dirinya dalam memahami konsep beragama khususnya terkait jihad dan juga faktor eksternal yaitu tindakan aktoraktor lain yang membantu Dian. Secara struktur, Dian adalah perempuan asal Jawa Barat lulusan SMA dan berprofesi sebagai pekerja migran di Taiwan. Keterlibatannya dalam kelompok ISIS dan dukungan dari jaringan ISIS inilah yang utamanya membuat struktur sosial Dian berani dalam tindakannya terlibat dalam jaringan dan aksi terorisme untuk mencapai tujuannya. Merujuk pada klasifikasi tindakan sosialnya Weber, tindakan Dian ini termasuk dalam tiga tipe tindakan sosial yaitu tindakan afektif karena merupakan inisiatif keinginan pribadi untuk bergabung dengan ISIS dan melakukan rencana aksi bom bunuh diri, tindakan berorientasi nilai dengan merencanakan aksi bom bunuh diri karena menganggap cara ini adalah jihad yang dapat membawanya ke surga dan memberikan syafaat surga kepada kedua orangtuanya, dan tindakan yang berorientasi tujuan dengan mengangap bom bunuh diri adalah cara yang paling efisien untuk segera 
mencapai tujuan pribadinya dalam mengabdi kepada Tuhan, mengabdi untuk orangtua, dan untuk kepentingan dirinya menuju surga.

\section{c. Tindakan Sosial Keterlibatan Tutin Sugiarti}

Keterlibatan Tutin Sugiarti dalam jaringan dan aksi terorisme dalam pembahasan ini utamanya dilihat dari dokumen surat dakwaan Tutin Sugiarti (Kejaksaan Negeri Jakarta Timur, 2017b). Dokumen ini berisikan biodata terdakwa dan informasi terkait keterlibatan dalam kasus yang didakwanya yakni terorisme. Tutin Sugiarti alias Umum Abza alais Ceuce binti Djaja ditangkap oleh Densus 88 pada 15 Desember 2016 atas keterlibatannya dalam perencanaan aksi bom bunuh diri yang melibatkan Dian Yulia Novi. Tutin yang menghubungkan Dian dengan Muhamad Nur Solikin untuk membantu rencana Dian untuk melakukan aksi bom bunuh diri.

Tutin adalah pendukung ISIS. Dia lahir di Ciamis, 25 September 1979 dan bekerja sebagai terapi herbal. Pendidikan terakhirnya adalah SMK jurusan Manajemen Bisnis. Sejak tahun 2006, Tutin aktif dalam beberapa pengajian khususnya yang membahas jihad. Dia banyak tahu tentang ISIS dan ajarannya terkait daulah islamiyah, hijrah, jihad, kafir demokrasi, thogut, dan lainnya melalui media sosial. Selain itu dia juga mengikuti pengajian anshor daulah di masjid lingkungan tempat tinggalnya dan grup Facebook yang juga membahas tentang perkembangan daulah serta penggalangan dana untuk kebutuhan istri-istri dari suaminya di penjara terkait terorisme (Kejaksaan Negeri Jakarta Timur, 2017b).

Tutin mengenal Dian melalui media sosial Facebook dan Instagram dan mereka sering membahas tentang jihad dan perkembangan daulah dalam jaringan ISIS sekitar tahun 2015. Tutin berkomunikasi melalui media sosial dengan Dian pada 2015 dan 2016. Melalui media sosial jaringan pendukung ISIS juga, Tutin berkenalan dengan beberapa orang lainnya termasuk Muhammad Nur Solikin. Dia juga bergabung dalam group Telegram pendukung ISIS bersama dengan Muhammad dan beberapa lainnya (Kejaksaan Negeri Jakarta Timur, 2017b).

Pada September 2016, Tutin membantu Dian untuk merealisasikan rencana Dian untuk melakukan aksi bom bunuh diri dan menikah sebelumnya dengan orang yang juga pendukung ISIS agar dapat membantunya. Tutin memperkenalkan dan menghubungkan Dian dengan Muhammad Nur Solikin sebagai pendukung ISIS yang dapat memfasilitasi rencana amaliyahnya untuk melakukan bom bunuh diri dan melakukan amaliyah (tindakan) bersama. Kemudian Tutin berhasil membantu proses perkenalan mereka hingga akhirnya mereka menikah dan melakukan rencana amaliyah bersama. Karena perannya inilah dan keterlibatan dalam jaringan kelompok teroris, Tutin kemudian ditangkap Densus 88 (Kejaksaan Negeri Jakarta Timur, 2017b).

Berdasarkan perjalanan Tutin dalam keterlibatan dengan jaringan ISIS, Tutin mengenal ISIS sampai terlibat kelompok ISIS melalui beberapa media sosial dan pengajian. Dia juga dianggap banyak mengetahui tentang pemahaman keagamaan yang diusung ISIS karena sejak 2006 mendalami kajian terkait isu-isu yang dipropagandakan ISIS dan juga melakukan kegiatan-kegiatan dalam jaringan ISIS melalui berbagai pengajian dan media sosial.

Sebagaimana dalam teori tindakan sosial, keterlibatan Tutin dalam jaringan dan aksi terorisme tidak terlepas dari agensi dan strukturnya. Tindakan sosial Tutin 
dalam jaringan dan aksi terorisme ini adalah keterlibatan secara aktif, sukarela dan langsung dengan mengelola jaringan ISIS utamanya melalui media sosial dan pengajian, memfasilitasi bantuan dana istri-istri jaringan ISIS yang dipenjara atau meninggal, dan menjadi penghubung atau fasilitator dalam jaringan ISIS dalam hal ini khususnya membantu Dian Yulia Novi dalam rencana melakukan bom bunuh diri dengan mencarikan suami sekaligus sebagai mentor dan pendamping dalam melakukan aksi terornya. Dalam konsep agensi, Tutin tidak hanya memiliki pengetahuan tentang ISIS dan jihad dan konsep-konsep keagamaan yang dipropagandakan ISIS sehingga dapat menjadi teman komunikasi dengan Dian sebagai pendukung ISIS yang baru bergabung dengan ISIS, tetapi Tutin juga memiliki jaringan kelompok ISIS yang cukup luas serta kemampuan yang dapat membantu Dian secara langsung dalam hal komunikasi, memfasilitasi, menghubungkan, dan menjodohkan Dian dengan Muhammad yang juga pendukung ISIS. Sehingga kelebihan Tutin dari internal dan eksternal ini membuatnya mampu melakukan tindakan sosial yang sangat mendukung pergerakan terorisme dalam lingkaran ISIS di Indonesia. Akan tetapi, meskipun Tutin lebih dulu terlibat jaringan ISIS dibandingkan dengan Dian, Tutin tidak seperti Dian yang memiliki keinginan untuk melakukan aksi bom bunuh diri. Tutin lebih banyak berperan dalam hal membantu jaringan ISIS khususnya membantu istri dan anak-anak dari para suami yang terlibat terorisme.

Pada akirnya, Tindakan Tutin lebih banyak dipengaruhi oleh struktur sosialnya dan tindakannya mengikuti pola gerakan jaringan ISIS melalui berbagai kegiatan dalam jaringan. Secara struktur, Tutin adalah perempuan dari Jawa Barat dengan pendidikan terakhir setara dengan SMA yang bekerja sebagai terapi herbal. Namun demikian, dia mampu menjadi salah satu aktor kunci yang mendukung langsung dalam gerakan jaringan ISIS di Indonesia. Dukungannya terhadap ISIS inilah yang kemudian membuat struktur sosial Tutin dapat membantu Dian melalui jaringan di kelompoknya untuk melakukan aksi terorisme. Dari perspektif Weber dengan klasifikasi tindakan sosialnya, tindakan Tutin ini termasuk dalam tiga tipe tindakan sosial yaitu tindakan afektif yang merupakan kehendak pribadi untuk bergabung dengan ISIS dan melakukan kegiatan-kegiatan yang mendukung pergerakan kelompok teroris ISIS di Indonesia, tindakan berorientasi nilai dengan membantu jaringan ISIS dengan membantu memfasilitasi kegiatan jaringan ISIS diantaranya membantu istri-istri dan anak-anak dari jaringan mereka dan membantu Dian Yulia Novi dalam rencana bom bunuh diri, dan tindakan yang berorientasi tujuan dengan membantu para istri dan anak dalam jaringan dianggap dapat mendukung gerakan jaringan dan membantu Dian dengan mencari orang yang tepat dapat membimbing Dian dalam melaksanakan rencana bom bunuh dirinya merupakan cara terbaik untuk mendukung gerakan ISIS sesuai kapasitasnya yang memfasilitasi kegiatan jaringan.

\subsection{Tindakan Sosial dalam Jaringan ISIS dan Aksi Terorisme}

Ketiga orang dalam pembahasan ini yakni Anggi Indah Kusuma, Dian Yulia Novi, dan Tutin Sugiarti dalam keterlibatan di jaringan dan aksi terorisme merupakan tindakan yang aktif atau dengan inisiatif pribadi, sukarela, dan secara langsung yang tidak terlepas dari pengaruh agensi dan strukturnya. Ketiga orang ini adalah pendukung ISIS, sebuah kelompok yang dinyatakan oleh PBB sebagai kelompok teroris berdasarkan Resolusi 2249 pada 2015 (United Nations, 2015). Di Indonesia, pada 2018 Pengadilan Negeri Jakarta Selatan memutuskan kelompok 
Jamaah Ansharu Daulah (JAD), sebuah kelompok yang memiliki afiliasi dengan ISIS dinyatakan sebagai korporasi terlarang. Ini artinya bahwa setiap kelompok yang memiliki afiliasi dengan ISIS, masuk dalam kategori korporasi terlarang (DW, 2018). Jauh sebelumnya, pengadilan di Indonesia juga telah memutuskan Jamaah Islamiyah (JI) sebagai korporasi yang terlarang (Kompas.com, 2008). Untuk penanganan kasus terorisme, Indonesia memiliki Undang Undang Penanggulangan Terorisme tahun 2018. UU ini pada awalnya adalah Peraturan Pemerintah merespon tragedi Bom Bali pada 12 Oktober 2002 yang kemudian direvisi pada 2018 untuk merespon perkembangan terorisme, termasuk ISIS dan jaringan foreign terrorist fighters di Indonesia.

ISIS atau juga dikenal sebagai Islamic State (IS), Daesh, Daulah Islamiyah, Khilafah Islamiyah atau Negara Islam Irak dan Suriah (NIIS) berdiri beriringan dengan konflik di Irak dan Suriah. Kemudian secara publik muncul pada 2014. Secara geneologi, kelompok ini adalah sempalan dari kelompok Al-Qaeda (Rijal, 2017). Akan tetapi, ISIS disebut sebagai kelompok yang jauh lebih ekstrem dari AlQaeda. Aksi kekerasannya yang khas dipertontonkan ke publik melalui medianya yaitu dengan melakukan pemenggalan kepada orang atau kelompok yang dinyatakan sebagai musuhnya (Byman, 2015). Karena propagandanya yang massif di berbagai media, ISIS berhasil menarik perhatian masyarakat Muslim di dunia dari berbagai negara termasuk Indonesia untuk bergabung dengan mereka dengan dalih hijrah dan jihad. Salah satu perbedaan ISIS dengan dengan kelompok-kelompok teroris sebelumnya yaitu ISIS melibatkan tidak hanya laki-laki tetapi juga perempuan dan anak-anak dalam aksi-aksinya (Wijaya, 2020). Tiga perempuan dalam penelitian ini para pendukung ISIS yang meyakini keterlibatan mereka dalam jaringan dan aksinya adalah bagian dari jihad.

Dari penjelasan di atas, tindakan sosial yang membawa ketiga perempuan tersebut terlibat dalam jaringan dan aksi terorisme utamanya adalah karena menjadi bagian dari pendukung ISIS. Keterlibatan mereka adalah bagian dari pelaksanaan komitmen baiat mereka terhadap ISIS. Jika merujuk pada konsep Weber yang mengklasifikasi tindakan sosial menjadi empat tipe, maka keterlibatan mereka dalam aksi dan jaringan terorisme masuk pada tiga tipe tindakan sosial yaitu tindakan afektif, tindakan berorientasi nilai, dan tindakan berorientasi tujuan yang baru mereka lakukan ketika bergabung ISIS dan memiliki paham dan tujuan yang sejalan dengan ISIS khususnya dalam pemaknaan jihad.

Ketertarikan ketiga perempuan ini dalam jaringan dan aksi terorisme khususnya terorisme ISIS melalui media sosial membuktikan bahwa ISIS berhasil melakukan manipulasi informasi dan propaganda secara global. ISIS terbukti memanfaatkan secara optimal strategi propaganda yang menarik bagi perempuan yang kemudian mendorong keputusan perempuan bergabung dengan mereka. Strategi ini juga diperkuat dengan pemanfaatan perkembangan teknologi internet, sosial media dan kanal aplikasi komunikasi untuk membentuk persepsi perempuan terhadap ISIS (Wijaya, 2020).

Meski demikian, tindakan sosial mereka masih dalam bingkai patriaki dimana hal ini juga menguatkan penelitian sebelumnya (Asiyah et al., 2020; M. Mulia, 2019). Keterlibatan mereka dalam jaringan dan aksi terorisme di Indonesia faktanya adalah sebagai pelaku atau aktor yang berperan penting dalam gerakan dan aksi terorisme. Namun di sisi lain mereka juga dapat dikatakan sebagai korban karena mereka merupakan korban propaganda ISIS, korban indoktrinasi agama 
dan korban kondisi yang diciptakan oleh kelompok terorisme yang dengan sengaja merekrut perempuan melalui media sosial dan berbagai media dan situs jaringan ISIS. Sehingga penelitian ini juga menguatkan penelitian sebelumnya dimana meskipun para perempuan tersebut adalah pelaku atau aktor (Sukabdi, 2021), mereka juga adalah korban (Asiyah et al., 2020; Mulia, 2019).

\section{Kesimpulan}

Keterlibatan perempuan dalam jaringan dan aksi terorisme secara langsung di Indonesia utamanya setelah adanya deklarasi ISIS secara global pada tahun 2014. Sebelumnya perempuan terlibat terorisme hanya sebatas pendukung tidak langsung, di ranah privat atau domestik, dan karena adanya hubungan pernikahan sebagai istri para pelaku terorisme. Setelah munculnya ISIS, perempuan yang terlibat terorisme ini kebanyakan adalah jaringan ISIS dimana hal ini merupakan modus, pola, dan strategi baru yang diciptakan, dilakukan dan dimanfaatkan oleh jaringan ISIS untuk merekrut perempuan karena dianggap memiliki banyak kelebihan untuk membantu perkembangan gerakan mereka meskipun masih dibawah dominasi patriarkhi. Keterlibatan para perempuan dalam jaringan dan aksi terorisme ini tidak hanya sebagai pendukung tidak langsung tetapi sebagai pendukung langsung atau sebagai pelaku (aktor) terorisme seperti dengan cara bom bunuh diri atau terror bom yang dilakukan secara individu, berkelompok atau pasangan suami istri dan bahkan dengan satu keluarganya dengan melibatkan suami, istri dan anak-anaknya. Keterlibatan perempuan dalam terorisme ini dipandang sebagai pelaku atau aktor terorisme tetapi juga sebagai korban terorisme utamanya dalam hal ini korban propaganda media ISIS dan indoktrinasi ISIS yang diciptakan oleh dominasi laki-laki di jaringan ISIS.

Keterlibatan para perempuan dalam lingkaran terorisme ini utamanya bersumber dari propaganda ISIS melalui berbagai media khususnya media sosial seperti Facebook, Instagram, dan Telegram. Hal ini menunjukan keberhasilan propaganda ISIS khususnya dalam rekrutmen terhadap perempuan melalui teknologi informasi internet. Keterlibatan perempuan ini karena beragam penyebab, faktor, dan motivasi mulai dari faktor internal sampai faktor eksternal diantaranya faktor agama, ideologis, tekanan kelompok atau orang terdekat, politik, kepribadian, latar belakang personal, identitas sosial sebagai Muslim, ibu sebagai pendidik anak, simbol perlawanan perempuan, pencarian indentitas, kepemilikan dan petualangan cinta melalui ISIS, trauma dan dendam istri atau anak kepada aparat, pengidolaan anak terhadap ayah yang pelaku teror, keterdesakan ekonomi, hubungan pernikahan, dan syafaat surga. Keterlibatan perempuan dalam terorisme juga memiliki beragam peran dan fungsi dan peningkatan peran diantaranya sebagai pendukung secara tidak langsung, pendukung secara langsung, pelaku bom bunuh diri, dan pemimpin kelompok teroris.

Berdasarkan tindakan sosial keterlibatan tiga perempuan yaitu Anggi Indah Mulia, Dian Yulis Novi, dan Tutin Sugiarti yang terlibat terorisme sebagai pendukung secara langsung dan sebagai selaku percobaan bom bunuh diri dapat disimpulkan keterlibatan mereka dalam jaringan dan aksi terorisme tidak terlepas dari agensi dan strukturnya. Tindakan sosial mereka dalam terorisme secara 
agensi dapat dikatakan keterlibatan mereka yaitu secara aktif, sukarela dan langsung berdasarkan pemikiran dan kehendak pribadi yang dipengaruhi factor internal dan eksternal dengan melakukan kegiatan-kegiatan untuk mendukung gerakan ISIS seperti propaganda ISIS di berbagai media dan membantu para istri dan anak di jaringan mereka, dan fasilitator kegiatan jaringan ISIS serta untuk tujuan pribadi seperti mengabdi kepada Tuhan dengan jalan jihad sesuai interpretasinya, mengabdi kepada orang tua, dan untuk masuk surga. Tindakan sosial keterlibatan mereka dalam terorisme lebih banyak dipengaruhi oleh struktur sosialnya dimana tindakannya mengikuti pola gerakan jaringan ISIS melalui berbagai kegiatan dalam jaringan.Dari klasifikasi tindakan sosial Weber, tindakan sosial mereka masuk tiga tipe dari empat tipe Weber yaitu tindakan afektif karena keinginan pribadi, tindakan berorientasi nilai dan tindakan berorientasi tujuan. Pada akhirnya, tindakan sosial para perempuan yang terlibat jaringan dan aksi terorisme ini merupakan bagian dari pelaksanaan komitmen baiat mereka terhadap ISIS dan pemahaman keagamaan berdasarkan interpretasi mereka yang sejalan dengan ISIS. Keterlibatan pada ISIS ini juga dapat dikatakan sebagai bagian dari struktur sosial mereka yang membuat mereka berani melakukan tindakan sosialnya.

\section{Daftar Pustaka}

Abdul, G. (2016). Ini Isi Surat Dian Yulia Novi, Calon Pelaku Bom Bunuh Diri. Fimela.Com. https://www.fimela.com/lifestyle/read/2675932/ini-isi-surat-dianyulia-novi-calon-pelaku-bom-bunuh-diri

Al Habsy, R. F. (n.d.). Perempuan dan Aksi Terorisme di Indonesia. https://suakaonline.com/perempuan-dan-aksi-terorisme-di-indonesia/

Amelia, F., Widodo, P., \& Budiarto, A. (2020). Motivasi Wanita Sebagai Pelaku Aksi Terorisme Di Indonesia. Jurnal Peperangan Asimetris, 6(1), 23-42.

Arnaz, F. (2018, January 3). Panitia Hijrah Militan ke Filipina Dibekuk Densus 88. Berita Satu. https://www.beritasatu.com/nasional/471664/panitia-hijrah-militanke-filipina-dibekuk-densus-88

Asiyah, U., Prasetyo, R. A., \& Sudjak, S. (2020). Jihad Perempuan Dan Terorisme. Jurnal Sosiologi Agama, 14(1), 125-140. https://doi.org/10.14421/jsa.2020.141-08

Azanella, L. A. (2021, March 29). Bom Gereja Katedral Makassar: Kronologi Kejadian, Keterangan Polisi, dan Sikap Presiden. Kompas.Com. https://www.kompas.com/tren/read/2021/03/29/100000165/bom-gerejakatedral-makassar-kronologi-kejadian-keterangan-polisi-dan-sikap?page=all

Bhakti, A. (2016). Perempuan dan Terorisme. Pakar. https://www.radicalismstudies.org/96/2016/02/reports/special-reports-andanalysis/perempuan-dan-terorisme.html

Bigio, J., \& Vogelstein, R. (2019). Women and Terrorism Hidden Threats, Forgotten Partners. Council on Foreign Relations, May, 1-44. https://cdn.cfr.org/sites/default/files/report_pdf/Discussion_Paper_Bigio_Vogel stein_Terrorism_OR.pdf

CNN Indonesia. (2021, April 2). Wajah Perempuan sebagai Martir Teror. Cnnindonesia.Com. https://www.cnnindonesia.com/nasional/20210401133448-12-624907/wajah- 
perempuan-sebagai-martir-teror

Detik.com, T. (2021). Daftar Pelaku Keluarga dalam Bom Bunuh Diri: Bomber Surabaya hingga Makassar. Detiknews. https://news.detik.com/berita/d5513399/daftar-pelaku-keluarga-dalam-bom-bunuh-diri-bomber-surabayahingga-makassar

DW. (2018, July 21). JAD Sah Dinyatakan Korporasi Terlarang. DW.Com. https://www.dw.com/id/jad-sah-dinyatakan-korporasi-terlarang/a-44891187

Hartana, I. M. R. (2017). Teroris Perempuan; Ancaman Faktual di Indonesia. Jurnal IImu Kepolisisan, 089, 45-50.

Ikhsan, S. (2020). Jihadis Perempuan Dalam Teror yang Berjejaringan. Pakar. https://www.radicalismstudies.org/1455/2020/01/reports/special-reports-andanalysis/jihadis-perempuan-dalam-teror-yang-berjejaringan.html

Jones, P., Bradbury, L., \& Boutillier, S. Le. (2010). Pengantar Teori-Teori Sosial. Pustaka Obor Indonesia.

Kasanah, N. (2021). Perempuan Dalam Jerat Terorisme: Analisis Motivasi Pelaku Bom Bunuh Diri Di Indonesia. IJouGS: Indonesian Journal of Gender Studies, 2(2), 34-43. https://doi.org/10.21154/ijougs.v2i2.3242

Kejaksaan Negeri Jakarta Barat. (2018). Surat Dakwaan Atas Nama Terdakwa Anggi Indah Kusuma alais Khanza Syafiyah Al FurqonSurat Dakwaan Atas Nama Terdakwa Anggi Indah Kusuma alias Khanza Syafiyah Al Furqon.

Kejaksaan Negeri Jakarta Timur. (2017a). Surat Dakwaan atas nama terdakwa Dian Yulia Novi alias Dian alias Ukhti alais Ayatul Nissa Binti Asnawi.

Kejaksaan Negeri Jakarta Timur. (2017b). Surat Dakwaan atas nama terdakwa Tutin Sugiarti alias Umum Abza alias Ceu Ceu.

Kinseng, R. A. (2017). Struktugensi: Sebuah Teori Tindakan Structugency: A Theory Of Action. Sodality: Jurnal Sosiologi Pedesaan, 127-137.

Kompas.com. (2008, April 22). Al Jamaah Al Islamiyah Korporasi Terlarang. Kompas.Com.

https://nasional.kompas.com/read/2008/04/22/00191667/al.jamaah.al.islamiya h.korporasi.terlarang

Kurnia, G. R. C., \& Sukabdi, Z. A. (2021). Salience Identity of Women in Terrorism. Gender Equality International Journal of Child and Gender Studies, 7(2), 135152.

http://journal.unilak.ac.id/index.php/JIEB/article/view/3845\%0Ahttp://dspace.uc .ac.id/handle/123456789/1288

L. Byman, D. (2015). Testimony Comparing Al Qaeda and ISIS: Different goals, different targets. Brookings. https://www.brookings.edu/testimonies/comparingal-qaeda-and-isis-different-goals-different-targets/

Maghfur, \& Muniroh, S. M. (2013). Perempuan Di Balik Teroris. Analisa, 20(2), 181-195.

Maharani, D. (2013, May 9). Hasil "Fai" Terduga Teroris Mencapai Rp 1,8 miliar. Kompas.Com.

https://nasional.kompas.com/read/2013/05/09/17593687/ Nasional 
Mulia, M. (2019). Perempuan Dalam Gerakan Terorisme Di Indonesia. Al-Wardah, 12(1), 80-95. https://doi.org/10.46339/al-wardah.v12i1.136

Mulia, S. M. (2018). Perempuan dalam Pusaran Fundamentalisme Islam. Maarif, 13(2), 14-26. https://doi.org/10.47651/mrf.v13i2.19

Musfia, N. W. (2017). Peran Perempuan dalam Jaringan Terorisme ISIS di Indonesia. Journal of International Relations, 3(4), 174-180.

Nafisah, N. F. (2021). Perempuan dan Teror: Memahami Peran Kombatan Perempuan dalam Kampanye ISIS. Jurnal Hubungan Internasional, 14(1), 125-141. https://doi.org/10.20473/jhi.v14i1.19618

Qori'ah, S. M. (2019). Keterlibatan Perempuan dalam Aksi Terorisme di Indonesia. Sawwa: Jurnal Studi Gender, 14(1), 31-46. https://doi.org/10.21580/sa.v14i1.2967

Rijal, N. K. (2017). Eksistensi dan Perkembangan ISIS: Dari Irak Hingga Indonesia. Jurnal Ilmiah Hubungan Internasional, 13(1), 45. https://doi.org/10.26593/jihi.v13i1.2670.45-60

Rizky, F. (2021, April 1). Fakta-Fakta Serangan di Mabes Polri dan Bom Bunuh Diri Makassar.

Sindonews. Com. https://nasional.sindonews.com/read/383134/13/fakta-fakta-serangan-dimabes-polri-dan-bom-bunuh-diri-makassar-1617239044

Rosyid, M. (2018). Perempuan dalam Jaringan Radikalisme vis a vis Terorisme Global. Muwazah, 10(2), 162. https://doi.org/10.28918/muwazah.v10i2.1782

Rufaedah, A., Sarwono, S. W., \& Putra, I. E. (2017). Pemaknaan Istri Napi Teror Terhadap Tindakan Suami. Jurnal Psikologi Ulayat, 4(1), 11-28. https://doi.org/10.24854/jpu12017-77

Saputro, M. E. (2010). Probabilitas Teroris Perempuan di Indonesia. Jurnal IImu Sosial Dan IImu Politik, 14(2), 211-228. https://doi.org/10.22146/jsp.10937

Sukabdi, Z. A. (2021). Risk Assessment of Women Involved in Terrorism: Indonesian Cases. International Journal of Social Science and Human Research, 04(09), 2495-2511. https://doi.org/10.47191/ijsshr/v4-i9-32

United Nations. (2015). Resolution 2249 (2015). In Security Council (Vol. 2249, Issue November). https://www.securitycouncilreport.org/atf/cf/\%7B65BFCF9B6D27-4E9C-8CD3-CF6E4FF96FF9\%7D/s_res_2249.pdf

Utama, A. (2017). Perempuan calon "pengebom" Istana Presiden dituntut 10 tahun. BBC News Indonesia. https://www.bbc.com/indonesia/41021645

Wening, A. K., \& Wahyudi, S. T. (2021). Analisis Kriminologi Keterlibatan Perempuan Dan Anak Dalam Tindak Pidana Terorisme Di Indonesia. Widya Yuridika, 4(2), 515-532. https://doi.org/10.31328/wy.v4i2.2278

Widyaningsih, R., \& Kuntarto, K. (2020). Determinan Keterlibatan Perempuan dalam Gerakan Radikalisme. MATAN: Journal of Islam and Muslim Society, 2(1), 40-56. https://doi.org/https://doi.org/10.20884/1.matan.2020.2.1.2251

Wijaya, T. I. (2020). Peran Manipulasi Informasi Terhadap Keikutsertaan Perempuan Dalam Gerakan Terorisme. Journal of Terrorism Studies, 2(1), 94-113. https://doi.org/10.7454/jts.v2i1.1019 